NBER WORKING PAPER SERIES

\title{
JAPAHESE STRUCTURAL ADJUSTMENT AND THE BALANCE OF PAYMENTS
}

Jeffrey Sachs

Peter Boone

Working Paper No, 2614

NATIONAL BUREAU OF ECONOMIC RESEARCH

1050 Massachusetts Avenue

Cambridge, MA 02138

June 1988

This paper is prepared for presentation at the Conference on Savings:

Its Determination and Macroeconomic Implications, sponsored by the Tokyo Center for Economic Research and the National Bureau of Economic Research, in Tokyo, January 1988 . This research is part of NBER's research program in International studies. Any opinions expressed are those of the authors and not those of the National Bureau of Economic Research. 


\section{NBER Working Paper \#2614}

June 1988

\section{JAPANESE STRUCTURAL ADJUSTMENT} AND THE BALANCE OF PAYMENTS

\section{ABSIRACT}

Polfcy discussions in Japan have Increasingly recognized the important role of land values and landuse patterns in Japanese macroeconomic adjustment. In Japan In recent years, land wealth constitutes pore than half of financtal wealth, a proportion that is wch higher than in the Unfted States and other Industrialized economies: Consequently, shtfts in land-use patterns can have loportant effects on Japanese savings and investment patterns, and thereby on the Japanese trade balance and current account. This papers studies tho liplications of land-use policies for the Japanese macroeconomy using both a theoretical model and a multisectoral dynamic simulation aodel.

\footnotetext{
Professor Jeffrey Sachs Department of Economics Harvard University Littauer $\mathrm{M}-14$

Cambridge, MA 02138
}

Professor Peter Boone NBER

1050 Massachusetts Avenue Cambridge, MA 02138 
Japanese Structural Adfustment and the Balance of Payments

A major goal of current Japanese economic policy is to shife from exportled growth to domestic demand-led growth, as part of a process of worldwide economic adjustment. The general objective is a reduction of the Japanese trade surpluses in future years (at least as a proportion of Japanese GNP), in Ine with a reduction of the $\mathrm{U} S \mathrm{~S}$ trade deficits, in a manner which maximizes Japanese economic welfare and minimizes the economic volatility during the adjustment process.

The case for domestic demand expansion is made on several interrelated levels A major argument is keynestan It is widely assumed the U.S. policy of reducing government deficits will zeduce japanese aggregate derand... In this view policy should attempt to of set that contractionary force with a domestic demand expansion. This same argument is sometimes put in cerms of Japan's global responsibllities: as the U.S. ceases to be the engine of global growth, some assert that Japan should substitute for the U.S.

Another case sometimes made for domestic-demand-led growth is that Japan is misusing 1ts high sayings by investing heavily abrosd cather than at home The argument holds that domestic distortions in the Japanese economy reduce domestic investment (e.g. in housing) and favor foreign investment, even though the social returns of incremental domestic investment would be higher. In this view, greater domestic demand in the form of efficient domestic investment should be encouraged. Yet another argument is that Japan showld 
reduce 1 ts large trade surpluses in order to reduce the risks of protectionism abrozd.

There are significant differences of opinion both within Japan and in the rest of the world about the kind of policies that Japan should pursue to spur domestic demand. In part those differences reflect different assessments of the functioning of the macroeconomy, and in part they reflect the fact that there are many differing motivations for wanting to spur domestic demand in the first place: There are three main schools of thought regarding possible policy measures. Ore view holds that as the U.S. pollcy mix changes (towards fiscsl contraction and monetary ease), and the dollar depreciates, normal market mechanisms $\$ 11$ lead to a rise of japanese domestic demand, even whour major policy actions by the Japanese government. 1 A competing view holds that such a market-based expansion would be insufficient to counterbalance U.S. flscal contraction, and that Japanese fiscal policy should therefore turn more expansionary, for 1ts own sake and for the rest of the world. ${ }^{2}$ A third view stresses the role of microeconomic policy actions in sputring domestic demand. An important argument is that changes in induse polfcy (including zonlng, land taxation, and import liberalization for foodstuffs) could spur housing demand, and well as investment in nonresidential structures, and thereby overall aggregate demand. ${ }^{3}$

The goal of this paper is to highlight some of the important effects which various pollcy options, particularily those relating to land-use, might have upon the Japanese economy. The linkages we discuss have not, to our knowledge, been exanined in the literature so date, and we consider their potential role from both theoretical and empirical perspective. The empirical work relies heavily on simulation models of the world economy, and 
of the Japanese economy. One contribution of the paper is to lilustrate how a multi-sector dynamic model of the Japanese economy can be used to assess the potentfal role of land-use policy in Japanese demand management. Our contribution here is mostly conceptual, however, since considerable further work wil be required to properly incorporate the range of factors which currently affect land-use, In particualr the role of fiscal policy and cax regulations.

The paper is organized as follows. In Section 2, we brlefly discuss the reasons for the global trade imbalances in the 1980 s, and for Japan's large trade surpluses in particular. The following sections then turn co a mult: sector simulation model of the Japanese economy, in order to evaluate (or at least show how to evaluate) the interactions of land-use measures and the macroeconomic balance. Section 3 considers the theoretical arguments for linking land use, the demand for structures (1ncluding housing and nonhousing structures), and the trade balance. Sectlor 4 presents a formal theoretical model, whlie Section 5 introduces the mult-sector model, and describes some of the simulation results. Since the results are very preliminary, there is ample reason in the concluding section 6 to suggest future lines of research In this area.

Section 2. Source of Global Imbalances and Japanese Policy Responses

General public opinion makes the fundamental mistake of viewing trade imbalances as a reflection of trade distortions, rather than as a reflection of savings and investment behavior usually unrelated to trade policies. while 
we wil indeed argue later on that there way be an effect of Japanese trade liberalization on the Iapenese trade balance (through effects on savings and Investment behavior that are typlcally neglected), theze is iltele reason to believe that the growing trade lobalances since the early 1980 s have been related in any impottant way wth changes fri trade policies in this decade. Ample research has stressed severai macroeconomic phenomena, rather than trade poilcies, that adequately account for the growing imbalances.

He enumerate the following major factors.

(1) The Japanese liberalization of the financlal makets in the early 1980s, especialy regarding international capital movements, which aliowed for the relatwely free outflow of japanese excess savings to the rest of the world;

(2) The divergent fiscel policles in the OECD couneries, especially the growth of U.S. Elscal deflcits and the reduction of fiscal deficits in Germany and Japen; and,

(3) The cutoff in lending to the debtor developing countries, which by forcing a reduction in trade defichts in the debtor countries, resuited in a corresponding increase in trade deffcits in the rest of the world.

In Sachs and Roubini (1987), a multi-country simulation model was used to assess, however roughiy, the quantitative role of these factors in accounting for the trade imbalances in the United States and Japan. For the U.S. trade balance, the Japanese trade balance, and the Yen-Dollar real exchange rate, the effects of the three factors were quantified, with the results reproduced in Table 1. In each case, the column labelled "actual change" records the change of the varlable in 1985 relative to its value on average during 1978 - 
Tabl- 1. Decoppostion of Changes in the External Balance and Bllateral Exchange Rate of che United States and Japan

Actual Predictod
Chang Change

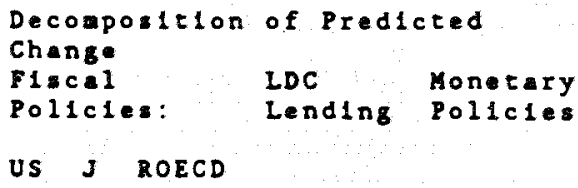

Var1abla:

\begin{tabular}{|c|c|c|c|c|c|c|c|}
\hline $\begin{array}{l}\text { U.S. Trade } \\
\text { Balance }\end{array}$ & -1.9 & -1.8 & -1.0 & -0.2 & -0.0 & $=0.4$ & -0.2 \\
\hline $\begin{array}{l}\text { Japan Trade } \\
\text { Balance }\end{array}$ & 3.2 & 2.8 & 1.4 & 1.9 & -0.1 & -0.6 & 0.3 \\
\hline $\begin{array}{l}\text { U.S. Japan } \\
\text { Real Exchang }\end{array}$ & 24 & 28 & 11.8 & 10.6 & -0.0 & -0.1 & 6.6 \\
\hline
\end{tabular}

Rate

Notes: The "actual changes" mesure the 1985 value of the varlable compared vith the verage value of the variable during 1978-80. The trade balance is measured as percentage of GNP. The real exchange rate measures the percentage change in the relative CPIs of the U.S. nd Japan, corrected for changes in the nominal exchange rate. The positive value signifles a real apprecition of the U.S. of 24 percent. The predicted changes come from lalation of the McKibbin-Sechs eodel based on changes in fiscal policles in the the U.S.. Japan (J), and the rest of the OECD (ROECD) of the historicaliy observed aagnitudes; an exogenous reduction in lending to the LDCs; and offseting monetary policies in the industrial countries. For detalls see Sachs and Roubini (1987).

Source: Sachs and Roubini, 1987 
80. In this perlod, for example, the Japanese trade balance improved by 3.2 percent of Japanese GNE, compared with 2.9 percent predicted by the multi. country model. Of the predicted 2.9 percent accounted for by the model, 1.9 percent of GND Improvement resulted from the Japanese fiscal contraction, 1.4 percent from the U.S, fiscal expanslon, 0.3 percent from monetary poifcies in the various regions, and -0.6 percent of GNP from the cutoff in lending to the LDCs.

The japanese liberalization of captral movements comes inco these estimates indirectiy. Sachs and Roubini point out that in the absence of liberabization of international capital movements, the large Japanese trade imbalances could not heve occurred. The Japanese fiscal contraction, for example, rather than inducing a capital outflow and a trade surplus, would instead have reduced domestic interest rates in Japan, thereby reducing private savings and increasing private investment. The fall in government dissavings would have then been belanced by rise dn private investment net of private savings.

It is evident from Table 1 that even a complete reversal of the U.S. fiscal poliey expansion of the first half of the 1980 s would not substantially eliminate Japan's large trade surpluses. This is because those surplises have resulted not mainly from the U.S. fiscal expansion, but from the contemporaneous Japanese fiscal contraction. According to the model in Roubini and Sachs, each reduction in U.S. government expenditure of 1 percent of GNP (which reduces the deficit by about 0.8 percent of GNP) reduces Japan's trade surplus by 0.4 percent of Japanese GNP. Even a deficit reduction of 3 percent of U.S. GNF (about $\$ 125$ b11110n in 1987) would have the effect of reducing the Japanese surplus only by about 1.5 percent of Japanese GNP. 
Is there a case then for augmenting a U.S. fiscal contraction with a Japanese fiscal expansion (i.e. to reverse, on both sides, the fiscal events of the 1980s)? On this we are sceptical, at least regards a significant Eiscal expansion (Japan Introduced a very modest fiscal expansion in 1987 . which has probably had a minor stimulative effect). 4 The best possible argument for an offsetting Japarese fiscal expansion is that a U.S. fiscal expansion would have highly coneractionary demand effects on the Japanese economy. But the theoretical and empirical evidence on behalf of that proposition is remarkably weak. In Roublnt and Sachs it is explained at some length that a policy mix of U.S. fiscal contraction and monetary ease (the present settings of U.S. policy) would likely be stimulative on balance for the Japanese economy, holding flxed the Japanese fiscal policy and money supply. The traditional Keynesian thinking holds that such a pollcy mix, by weakening the dollar, will tend to depress Japanese export demand, and thereby lower Japanese overall demand. What that analysis underestimates empirically Is that the policy mix will also allow for a significant reduction in interest rates, which will spur the non-export portion of Japanese demand. In other words, a tight-Eiscal, easy-money policy in the U.S. will automatically spur Japanese domestic demand at the same time that it depresses demand for Japanese exports. In sum, the overall effects of the U.S. policy mix on the level of Japanese output will probably not be large, and may well be positive.

There is a final important point to make in assessing the effects of U.S. policy changes on other economies, such as Japan. The size and even direction of responses outside of the U.S. depend on the nature of wage setting in the foreign economies. In general, the high flexibility of 
Japanese labor costs whll tend to mute ary employment effects of U.S.

macroeconomic policy chariges. Japanese nominal wages will tend to adjust rapidiy to offset any contractionary effects of U.S. policy ections.

The case for significant Japanese fiscal expansion might stili be made, not on aggregate demand grounds, but on the pucative urgency of reducing the Japanese trade surplus at any cost. It is indeed true that a japanese fiscal expansion would have a significant effect in reducing the trade surplus (approximately 0.7 percent of GNP for each 1 percent of GNP fiscal expansion. according to the ectmates in Sachs and Roubini, and by a stuflar amount in the model reported beiow). But in balancing the benefits of a reduced trade surplus (in serms of reduced international tensions) with the harms of renewed large fiscal deficits, It seems to us that the "cure" of a fiscal expansion could welI be worse than the "disease". The same is true of s return to capital controls. A refmposition of captal controls, even with unchanged fiscal polfcies, could substantially reduce Japan's trade suppluses. Such a policy would prevent further captal outflows, and thereby tend to reduce Japanese interest rates and to spur private investment. But again, there would be high costs (both to the financlal sector and to the economy as a whole) of reversing several years of financial lfberalization, and the putative benefits of reduced international frictions from a cut in the trade surpluses probably do not justify such a course of polfcy.

\section{Land Use Polfcies and the Japanese Balance of Payments}

Because of the obvious shortcomings of renewed fiscal deficits, or renewed 
capital controls, policymakers have been examining other methods of spurring domestic Investment (and with less enthuslasm, of reducing private savings). One set of pollcles, outside of the focus of this paper, Involves a possible broad-based tax reform to encourge investment and discourage savings. Another set of policles 1nvolves landruse maragement, with focus on new weans of stloulating hous1ng investment (and perhaps lnvestment in nonresidential structures) by shifting more of Japan's scarce land resources 1nto structures and out of alternative uses.

Japan's land scarclty puts the macroeconomic role of land in Japan into unusual macroeconomic prominence: Land is rarely discussed in macroeconomic models (Including, unfortunately. standard macroeconomic models of the Japanese economy), but its central and unique macroeconomic significance in Japan should be noted: Remarkably; as seen in Tabie 2 ; the value of clafms to land in Japan accounted for about 54 percent of Elnancial wealth in Japan in 1984, as opposed to a mere 24 percent in the United States. The value of land equalled about 317 percent of GNP in 1984, as opposed to 80 percent of GNP in the United States, For this reason, changes in land values should be expected to have major significance for patterns of savings and consuption in Japan :

High land prices mean that a significant proportion of the cost of housing and non-residential investments in structures is due to the cost of the land component of the investment. For ali structures (1ncluding housing and nonresidential structures), the share of land in the total value of structures (1.e. the sum of reproduc1ble cap1tal plus land) averaged about 71 percent $1 n$ Japan in 1984. (the data avallable to us did not allow us to break out housing versus nonresidential structures). In the U.S., this ratio was on the order of 31 percent. 6 In heavily concentrated urban areas, espec1ally 1n Tokyo, the 
land component is far higher. A recent estimate holds that for public investrent spending in the Tokyo area, costs of land acquistion account for about 95 percent of project costs.

Such a high share may have profound implications for the effectiveness of fiscal policies. To the extent that bord-financed public investment spending covers malniy the costs of land acquisition, rather than an expenditure on final goods and services, the public spending is reaily a swap of assets (land for bonds) rather than a purchase of goods and services. The aggregate demand effects of such an asset swap ore cotolnly less stimulative (1) present at a1) then are the demand effects of a bond-financed purchase of finel goods. The price of land has recently had an even more direct effect on macroeconomic policies in Japan, since the Bank of Japan has cited sharply rising land prices in 1987 as a reason to avold further monetary expansion or further cuts in interest rates. 9

The argument wade for land-use changes revolves around varlous policies that currentiy act to ralse the price of land for residential housing and business investment in structures, and thereby contribute to a lower flow of structures investment and a lower stock of structures capital. Japan's housing stock as a percent of GNP is also shown in Table 2 . It is clear that Japan's stock of physical capital in housing, equal to 53 percent of GNP, and only 9 percent of net worth, is significantly below the shares in the U.S., which are 90 percent of GNP and 27 percent of net worth. The share of housing capital in GNP is also below the ratios in the U.K. and Germany (for which comparable data are available). Interestingly, no shortfall is evident in nonresidential structures: in Japan they equalled 51 percent of GNF, versus 52 percent of GNP in the U.S. There is apparantly a considerable amount of land in 
agriculture in Japan that could provide space for housing. Farmland accounts for 19 percent of the total land value in Japan, and much of ft is close to urban areas. Tokyo alone has about 130 kilometers square of farmland in the metropolitan area. 10 In terms of cotal area, farmland accounts for roughly 158 of total land, while housing cakes up only $3.8{ }^{11}$

Four kinds of policles sre sliazed to contribute to the high costs of residential investment. First, protectionist agricultural policies, especially for rice, keep domestic food prices far above world levels, and encourage the use of domestic land for inefficlent agricultural production zather than investment in housing and other structures Approximately half of all Japanese arable land is in rice production.

Second, varlous tax policies favor the use of land for agrlculcure rather than for housing. Inheritance taxes on agricultural land are far more favorable than similar taxes on residential real estate. similarly, property taxes are far higher on residential than on agricultural properties. Another indrect factor comes from the abllity cf farmers to hide their income more easily than salaried workers. It is often reported in the Japanese press that only one-third of farm incomes are ever actually reported to the tax authorities. These tax differentials of course give the incentive to limit the land available for housing, as well as to maintain employment in agriculture. 12

Third, various zoning laws ralse the amount of land required per unit of housing services, by limiting the development of high-rise units in urban areas that could economize on land requirements. These zoning laws include so-called "sunlight provisions", which ostensibly given homeowners the property right to sunlight and thereby hinder the construction of buildings 
that would block the sunilight of existing buildings, as well as archaic anti. earthquake zoning ordinances, that have been rendered obsolete by new construction trethods. The result is that Tokyo, for example, is one of the lesse dense of the very large cities in the industatailzed world.

A fourth limtation on land use is the large proportion of land that is held, and not developed, by the goverment. The Japar National Ralinay is reported to be the country's largest landowner, with very extensive holdings of undeveloped land. This suggeses that a fiscally neutral why to finance Euture publio investment spending could be through iarge-scale assot sales of public land holdings. The sales would both provide revenues for fiscal expentiture, and also contribute to a rise in housing investuent by increasing the avallable stock of land.

These restrictions on land use are at the center of pubilc discussion, though not yet at the center of technical economic andisis. Several major combissions, inciuding the Maekawa comission and the Okita Commision, have urged changes in these four policy areas as ways to spur domestic demand and to improve the neton's housing stock. ${ }^{13}$ surptishigly, however, stancard macroeconomic models have paid little attention to these posstble chanels, ${ }^{14}$ A complete discussion of the whole range of channeis linking land-use policy and wacroeconomic performance is beyond the scope of this paper, so the rest of this section is devoted to introducing a simple framework for analyzing a particular set of channels, and the nexe sections embeds that framework in a large-scale simulation model. It is important to point out that there are many linkages between land-use and tax and trade policies, and that the following discussion is only a preliminary look at the nature and extent of a subset of these linkages. 15 
The key to modelling the land-use issue is to recognize that land is both a critical store of value as well as factor of production. Moreover, as a factor of production, there are competing demands for land in agriculture, housing. and other commerclal and public uses. We will focus mainly on the simple case in which land is used solely for agriculture and housing. In the following sections we explicitly aliow for land use in non-residential structures, but for analytical purposes we focus upon this simple case in order to provide the basic intuition into the linkages we wish to discuss.

The total stock of 1 and will be denoted $L_{\text {, }}$ of which $L_{F}$ is in the food (agriculture) sector, and $L_{H}$ is in the housing sector. The main analytical polnt is that changes in 1 and-use patcerns between the agricultural and housing sectors affect both savings and Investment. A policy of trade Lberalization, for example, 111 depress domestic food prices and thereby reduce the value of wealth in agricultural land. This decline in land values represents an 1mportant decline fritealth for consumers, and hence wi1 tend to reduce consumption and raise national savings on the other hand, the Lower land prices will generally reduce the cost of providing housing services (whlch include both the cost of the land and the physical capital in housing). and thereby stimulate housing investment until the stock of housing reaches a new higher plateau. Thus, both savings and investment tend to rise, with the effect on Japan's overall external balance determined by the change in savings Inus the change in 1nvestment.

The effect of the varlous policies upon macroeconomic variables depends cruclally upon the wealch effect on savings. The magnitude of the change in total savings will depend upon how large the change in land values actually is, and upon how much individuals adjust savings in response to these changes 
in wealth. The change in total land values will depend upon a number of inter-realced issues. In this paper we focus on one linkage: the relationship between the price of agrlcultural goods and the price of land. Thus any change in the price of food is assumed to resuit in an equal percentage change in the marginal product and hence value of 1 and. In actual fact there are a number of factors, most notabiy the tax regulations described above, which could also critically affect the value of land, and which wight break the oneto-one Inik between food prices and land values. In our theoretical model we allow for this in the case where there are lump sum tax subsidies to land, and in the simulation wodel we make adjustments so that the fali in land wealth is not proportional to the fali in food prices, but further research will be necessary to properly study these other linikages, and point out that our findings could change substantially once these factors are incorporated.

The effect of the change in land values upon personal savings will depend on the demographic distribution of land holdings and the nature of intertemporal transfers. In an overlapping generations (Olo) model, for example, all assets (Including land, housfng, equity claims, foreign bonds) 16 are held by the older generation. since the young start off only with their labor income, and accumulate assets over time to finance consumption in old age. Assuming no bequests, the old sell off their assets to young, and use the proceeds to finance expenditures after retirement. In this framework, a decline in land values has a very large effect on consumption, since the old must reduce their consumption one-for-one with a capital loss on land. Thus, if a trade liberalization occurs which depresses farw land prices, the older generation will sharply cut back on consumption. At the same time, the young will neither cut back nor sharply increase their consumption, since their 
labor Income is not directly affected by the trade liberalization. The result is a significant increase in the national savings rate. Because of the rise in the savings rate, the current account surplus could well increase, despite a significant rise in housing investment in the short term.

Indeed, we will note below that in one important model, an economy starting In current accoune balance will han curnutative current account surplus during the adjustment period after a fall in land prices. The investment boom in housing is short-lived, ending once the stock of houses reaches its new plateau. On the other hand, the depressing effect of lower land prices on consumption persists, leading to teade surpluses, and an accumulation of foreigr assets. The foreign assets ultmately grow enough in the model below to push consumption back up and to rebalance the current account over the course of adjustment, then, the erade liberalization leads to an increase in net foreign assets.

The 11kl hood of trade deficits lmediately following a liberalization of food trade (or other policies that lower land prices) rises with the length of the planning horizon of the households. With long-lived households the drop In land wealth does not produce matching one-for-one drop in consumption, but rather a much more modest drop in consumption. The loss of wealth is now smoothed over a very long consumption horizon. For example, an infinite-lived household can maintain a constant consumption stream by always consuming an amount equal to the interest rate times les wealth (1.e by consuning the income earned on the stock of total wealth). If a component of wealth falls, therefore, complete consumpeion smoothing would require that the household reduce its spending not by the full amount of the wealth loss (as in the OLG model), but by the interest rate times the wealth loss. Thus, the fall in 
national consumption is much lower, the rise in national savings much less, and the chance much greater that the induced rise in housing investment w11 exceed the rise in national savings.

The long-run effects of a trade liberalization on the net foreign investuent position of the econory can be understood in another way. Most models of savings behavior of finte-11ved housebolds produce equilibria in whth the econouy has a flxed steady-state ratio of financial wealth to human wealth. This is because the accualution of fingneial wealth comes frow savings of the young out of their labor earnings. Financial weat th inciudes

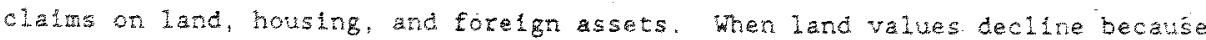
of a reduction of food prices, the velue of land in total yealtiblis. Assuming that total wealth fs thchanged in the new long-run equitibrium whick w11. be the case 1 labor amings are not drectly affected by the crade

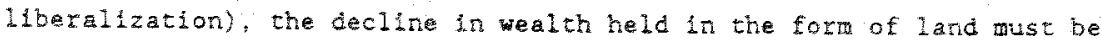
belanced by a rise an wealch held in the form of housho and forefgr assets. But the value of wealth held in the form of housing is equal to the discounted value of consumet expenditures on houshng services, which itself will tend to be a fixed proportion of human wealth assuming that a constant share of spending is allocated to housing. Thus, if land wealth falls, and housing wealth remains unchanged, net foreign assets must rise in order to keep total weal th unchanged. In long-run equilibrlum, therefore, the fall in land wealth is balanced by a rise in net claims on the rest of the world. On the transition path, there must be current account surpluses on balance in order to generate the steady-state rise in net forelgn assets.

Section 4. A Formal Model of Land Use in the Macroeconomy 
Consider the following formal framework, which is the basis of the large simulation model in the next section. The stock of land is distributed between housing and agraculture as previously described:

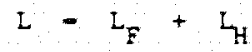

Food is produced using only land (this assumption is made here only for convenfence; it is relaxed in the simulation model). Without loss of generality, we normalize units so that one unit of land producés one unit of food:

$$
F-L_{F}
$$

For simplicity, the output all other final goods is denoted by $Q$, and is assumed to be flxed, produced by a flxed stock of labor.

(3) $Q-Q$

The discounted value of the stream of current and fucure $Q$ is the value of human wealth in this model. The output $Q$ is used for investment in housing, I) final domestic consumption expenditure $C_{Q}$ and exports, $X$; so that $Q-I$ $+C_{Q}+X$

The housing stock (and also the flow of housing services, which is assumed to be a fixed ratio of the housing stock) depends on reproducible capital in housing, $K$, and land, according to a fixed proportions production technology: 
(4) $\mathrm{H}=\min \left\{\mathrm{K} / \mathrm{u}, \mathrm{L}_{\mathrm{H}} / \mathrm{v}\right.$ )

We assume that housing is provided by a housing industry, which purchases the land and makes the captal investment. A unit increase of housing stock requires $u$ units of physical capital, and $y$ units of land, and so has a cotal purchase price of: $u+v * q_{F}$ where $q_{F}$ is the price of anit of land. Equilibrium requires that the market value of an existing house, $q_{4}$ - should also equal its reproduction cost. (This arbitrage relationship

assumes that there are no costs of adjustment in altering the stock of housing either in a positive of negative drection. In the simulation model, costs of adfustment due to capeclty constraints in the construction industry alter the arbltrage relationship sightly.) Therefore:

(5) $q_{H}-u+v * q_{F}$

In addition to the problem of adjustment costs, there are several important qualifications that must be made to (5). Most importantly, the model so far assumes that all land is homogeneous, and equally substiturable between housing and agriculture. Land, however, is almost inherentiy heterogeneous, In that land in different locations will earn differing spacial rents. Land in downtown Tokyo of course greatly exceeds the price of 1 and on the metropolitan fringe. There is another factor of production, location, that earns rents and contributes to the value of houses. Empirically, it will be 1mportant to account for those spatial rents. A percentage change in $q_{F}$ will have a far larger effect on the proportionate change in housing costs in the 
fringe than in the city center. We return to the theme of spatial rents in a later subsection:

The price of ant of land is given by the discounted value of future marginal value products of land in the agricultural sector, plus any subsidies $s$ that might be given to landowners. Each year, a unit of agricultural land earns rental $p_{F}$ plus the subsidy $s$. The price of land is such that the total yield on land (captal gains plus rental yleld inclusive of the subsidy) should equal the market interest rate:

$$
q_{F} / q_{F}+\left(p_{F}+s\right) / q_{F}-z
$$

In a full steady state, with $P_{F}, s$, and $r$ all constant, (6) reduces simply to:

(6) $q_{F}-\left(p_{F}+s\right) / r$

of course the land subsidy would have to be financed through other taxes, $I$, with a present value $T-(s * F) / r$.

Slmilarly, the full return on a house should also equal the market return. With rental payments equal to $p_{H}$ we have the following:

(7) $q_{H} / q_{H}+p_{H} / q_{H}=r$

In a steady state, with $p_{H}$ and I constant, we have:

(7') $q_{H}=p_{H} / r$ 
The model is closed by specifying consumption demand and the warket clearing conditions. We use here, without detailed elaboration, the Blanchard model of identical individuais who maximize intertemporal expected utility, subject to the probability $p$ of death each period. When pmo, the model behaves like the case of households with an infinite hortzon. When $p$ is close to one, the model behaves more like an overlapping generations model.

Intertemporal opeimization leads to a simple formulation for consumer behavior. Each household consumes a constant proportion of its total wealth each perfod, with the proportion equalling $d+p$, where $d$ is the subjective rate of time discount:

(8) $c=(d+p) w$

We assume that the parameters have values such that: $r>d>r \cdot p$. The first Inequality assures that the stock of non-human wealth is positive. The second inequality is made to assure stability. 17

One criticism of our model specification is that it 1gnores the possibility of target savings for house purchases. Ito, Hayashi, and slemrod(1987), amongst others, have discussed how savings in Japan may be artificaliy high due to credit warket imperfections which cause the young to save for large down payments towards housing purchases. Any polfcy which resulted in a change in the price of a housing unit could in turn affect the steady-state level of wealth by changing the savings of the young for this purpose. Our model, which assumes perfact capital markets, ignores this so-called "house savings" phenomenon. Both the dynamic and long-run effects of changes in the 
price of land on savings due to this motive are quite complicated. In particular, they will depend upon the nature of the underlying liquidity constralnt, upon the elasticity of demand for housing services, and upon whether or not the optimal timing of an initial purchase changes when housing prices change. The linkage of "house savings" and land values will be considered in future research. 18

Total wealth, $W$, is the sum of human wealth, $E$, foreign assets, $B$, houstng wealth $q_{H} * H$, and wealth in farmiands, net of taxes $T$ :

(9) $-E+B+q_{H} * H+q_{F} * F-I$

Human wealth is just the discounted value of the exogenous output flow $Q$. A key to Blanchard's model is to note that for an Individual agent, human wealth Is discounted by $(r+p)$ rather than simply $r$, since after the agent dies, the flow of labor income associated with the particular agent vanishes. Thus,

(10) $E-Q /(r+p)$

We will denote all wealth except $E$ as non-human wealth $N E-H-E$.

Finally, we divide total consumption among its constituent parts we . assume that households spend a constant share of their consumption on food, housing, and the rest, so that:

(11) (a) $P_{F} * C_{F}=s_{F} * C$

(b) $\mathrm{P}_{\mathrm{H}} \star \mathrm{H}-\boldsymbol{s}_{\mathrm{H}} * \mathrm{C}$

(c) $C_{Q}-\left(I-s_{F}-s_{H}\right) * c$ 
Total exports are glven by output $Q$ minus $C_{Q^{\prime}}$ minus investment in housing. I. Total imports are simply net imports of food, given by $C_{F} \cdot F$ (we assume, without loss of generailey, that the world prices of $Q$ and $F$ are both equal to 1.0). Thus, the trade balance is given by:

(12) $T B=Q+F \cdot\left(C_{Q}+C_{F}\right) \cdot I$

The overall current account, with equals the instantaneous change in $B$, is then given by:

(13) $B-I B+T B$

We assume perfect capital mobllity with the interest rate $r$ flxed exogenously in world markets such that agents can borrow and lend freely at the international race $I$, subject only to thelr long-term budget constraint.

The model is closed with alternative assumptions about the food market. Under conditions of completely prohlbited trade in food, as now exists in Japan with respect to rice, the food market must obey $C_{F}-F$, with the domestic price $P_{F}$ greater than the world price $P_{F}{ }^{\star}=1$. Alternatively, with free trade in food, we must have domestic and world prices equal. Thus, we w111 use two alternative assumptions:

(14)(a) $C_{F}-F \quad$ (food autarky)

(b) $P_{F}=P_{F}{ }^{\star}-1 \quad$ (free trade in agriculture) 
It is useful to note that under either assumpton, the current account equation in (13) can be rewritten as GNP net of total consumption and total investment (the term in parantheses is GNP):

(13') $\mathrm{B}-\left(\mathrm{rB}+\mathrm{Q}+\mathrm{P}_{\mathrm{F}} * \mathrm{~F}+\mathrm{P}_{\mathrm{H}} \star \mathrm{H}\right) \cdot \mathrm{C}-\mathrm{I}$

To see how to get from (13) to $\left(13^{\circ}\right)$, note that we can add and subtract $p_{H}$ * $H$ to the right hand side of (13) to obtain as the RHS, rB $+\mathrm{Q}+\mathrm{F}+\mathrm{PH}_{\mathrm{H}}$ $\mathrm{H}-\left(\mathrm{C}_{\mathrm{Q}}+\mathrm{C}_{\mathrm{F}}+\mathrm{P}_{\mathrm{H}}{ }^{\mathrm{H}}\right)-\mathrm{I}$ - Then note that $\mathrm{F}-{ }^{-} \mathrm{C}_{\mathrm{F}}$ equals $\mathrm{P}_{F} *$ (F) $\left.-C_{F}\right)$ under e1ther $(14)(a)$ or $(14)(b)$. Then, we can substitute for $F \quad C_{F}$ In the RHS of (13), and replace the sum of the components of consumption by overal1 consumption $C$. We thereby arrive at (13').

We now consider number of alternative experiments. The first is trade Iberalization, 1.e. a shift from equation (14)(a) to equation (14)(b). Then, we turn to a shift in land taxes and a change in the land-house ratio. In the next subsection we analyze the steady-state implications of these changes, and in the subsequent subsection we examine the dynamics.

Steady-state effects of the policy changes

To understand the workings of the model, note first that there is a fixed rat1o of non-human wealth, NE - W E, total wealth, E, housing wealth, and total consumption spending, $C$, to. $Q$. These ratios are found by setting the current account equal to zero, and substluting the various values for wealth and consumption. The results are as follows: 


$\begin{aligned} \text { (15) (a) } \mathrm{NE} & =\mathrm{a}_{1} * \mathrm{Q} \\ \text { (b) } W & =a_{2} * Q \\ \text { (c) } \mathrm{a}_{\mathrm{H}} * \mathrm{H} & =\mathrm{a}_{3} * \mathrm{Q} \\ \text { (d) } \mathrm{C} & =\mathrm{a}_{4} * \mathrm{Q}\end{aligned}$

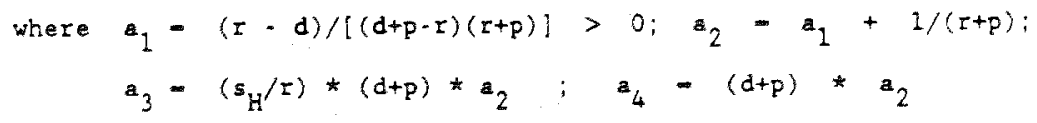

Now note what happens when a trade liberalization occurs. The price of food falls to world levels, and the price of land, which is the discounted value of food prices, also falls in the same proportion. It should be clear from (15) that total wealth and non-human wealth must gemain unchanged in the now stoady state after the shift in policy. Moreover, the wealth in the housing stock $\mathrm{qH}$ * $\mathrm{H}$ wil also be unchanged, with $\mathrm{q}_{\mathrm{H}}$ falling while the physical housing stock $\mathrm{H}$ rises. In the new steady stace, the decline in land wealth will be matched by a rise in net forefgr assets. ${ }^{19}$

To calculate the long-run decline in land wealth, note that the price of a unit of land falls in equiproportion to the drop in the price of food. This causes the value of housing unit to fail by a smaller proportion, since lanc constitutes only a fraction of the value of a house. The change in the level of $\mathrm{q}_{\mathrm{H}}$ is simply $v$ multiplied by the change in $q_{F}$. The change in the quantity of housing is the inverse of the change in $q_{H}$, since the product $q_{H}$ * $H$ does not change. The change in $H$ determines the change in $F$, since $H+F=I$. Therefore, we can now calculate the total decline in land wealth, $q_{F}$ * $F$, since we have derived the fall in $F$, and know the fall in $q F$ already. The 
rise in $B$ in the steady state must match the fall in $q_{F} * F$, in order that total wealth remains unchanged.

As we will see in the next subsection, the dynamic adjustment path is more complicated, however, because the shift in policy spurs a rise in the physical quantity of the housing stock and the stock of non-residential structures. At the time of the liberalization, housing investment rises, tending to drive the economy into a temporary current account deficit. The boom in housing is short-lived (Indeed instantaneous in this particular model), however, and the economy moves to trade surplus. Thus, the net forelgn asset stock intially falls, but then rises again to above the initial level.

In the more carefully specified stmulation model of the next section, the Investment boom in housing extends beyond the first period. This is because housing investment in the more laborate model is supplied by construction Industry, that produces houses with a rising marginal cost in the short term. Thus ther ar "external" cost of adjustment in the short-run housing boom, with the price of housing being bid up by the limited capacity of the construction industry. This short-run rise in construction costs has the effect of spreading out over several periods the adjustment of the physical stock of housing.

We can similarly use the theoretical framework to study the effects of other types of changes in land policy. Consider, for example, a policy of reducing the current tax preferences in favor of agricultural land, which are proxied by the subsidy $s$ in the model. It is simplest to study a reduction of $s$ In the free-trade version of the model, in which domestic food prices are fixed at world levels. In this case, the presence of the subsidy drives up the value of a unit of land $q_{F}$ in the amount $s / r$, and thereby drives up the 
value of unit of housing. $q_{H}$, since $q_{H}$ is equal $\left(u+v \star q_{F}\right)$.

Since $q_{H}$ * $H$ is a fixed altiple of $Q$, the rise in $q_{H}$ due to the subsidy $s$ must be matched by a fall in the physical housing stock H. Since total land is equal to $L=F+7 k H$, lower $\mathrm{H}$ means greater $F$. In sumnary, a subsidy to agricultural land raises the price of farmland, and causes shift in land allocation from housing to farmland.

Note that the subsidy on farm land must be financed with offsetting taxes. Each period the subsidy is $s * F$, so that the discounted value of offsetting taxes is $T=(s * F) / T$. Note that the value of farm land net of taxes is $q_{F} \star F-T=$

$\left(\left(P_{F}+s\right) / r\right] * F *(s * F) / r-\left(P_{F} * F\right) / r$. Under free trade, $P_{F}$ is flxed on world markets.

Now, suppose that $s$ is reduced from a positive level to zera. Clearly, the housing stock $H$ will rise and $q_{H}$ will fall, with $q_{H} * H$ remaining unchanged in the new equilibrium. The value of land net of taxes is reduced, since $F$ will fail as $\mathrm{H}$ rises. Total wealth must remain unchanged, as do housing wealth and human wealth, while farm wealth net of taxes must fall. Therefore, net foreign assets $B$ must rise. Once again, the shift in policy causes a rise in the physical stock of housing, as well as a rise in the long-run net foreign investment position. The result, therefore, is likely to be a short-run current account deficlt as the investment boom in housing takes places, followed by even greater current account surpluses in the future as households rebulld their stocks of wealth.

As a third kind of experiment, consider a shift in zoning which allows for more housing per unit of land. A simple example would be an easing of restrictions on the construction of high-rlse apartment bulldings. In this 
case, the parameter $v$ is caused to fall, since $v$ measures the land input to a unt of housing service. Consider the Implications under a free trade regime, In which $P_{F}$ is flxed on world markets. When $v$ falls, the value of a unit of housing will also decline in the steady state, since $q_{H}-u+v * q_{F}-u+v *$ $\left(p_{F} / r\right)$ The fall in $q_{H}$ results in a rise in $H$ in the long term, since the product of $q_{H}$ and $H$ are fixed. Therefore, as in the previous example, the land in farms, $F$. must $f a l l$, and the value of wealth in farmland must also decline The result w11 be an offsetting Increase in $B$. Once again, the likely time path for the economy will be that the reduction in $v$ is followed by a housing boom and current account deficlts in the short term, and a sequence of even larger current account surpluses in the future.

Dynamic Adjustments to the Policy Changes

With little preliminary rewriting of the equations, the dynamic adjustment process is surprisingly easy to specify. We focus here on the example of trade liberalization. The other cases can be worked out by close analogy. The key is to consider the dynamics of wealth adjustment. Total wealth is equal to $W-Q /(r+p)+q_{F} * F+q_{H} * H+B-T$ From the housing arbitrage condition, $q_{H}-u+v \star q_{F}$, so we can see that $q_{F} \star F+$ $q_{H} \star H-q_{F} *(F+v * H)+u * q_{H}-q_{F} \star L+u \star H-q_{F} \star L+K$, where $I$ is total land, and $K$ is the stock of housing capital. Moreover, for all of the experiments that we are considering, $q_{F}$ is fixed ( usually at $q_{F}=p_{F}{ }^{*} / x-$ $1 / x$ ) after the policy change. Thus, we may write:

$W=Q /(r+p)+q_{F} \star L+K+B-T$. Along the adjustment path, the following vartables are flxed: $Q, r, P, q_{F}, L$, and $T$. Thus, in rate of 
change form, long the adjusment path we have:

(16) $-\mathrm{NE}-\mathrm{K}+\mathrm{B}$

Ac the moment of a policy change, however, will change discretely when $q_{F}$ changes discretely. Let $d\left(W_{0}\right)$ signify the discrete change in wealth at the Instant of the pollcy change. At the instant of the change, the only possible wealth effects are the change $i n g_{F}$ and the change in $T$, since the sum $K+B$ 1s fixed any instant. Thus:

(17) $d\left(W_{0}\right)-d\left(a_{F O}\right) *^{-} I-d\left(I_{0}\right)$

(In the trade liberalization example, $d\left(T_{0}\right)-0$ ).

Now, turn to the balance of payments condition (15). We know that $Q+p_{H}$ $\star H+P_{F} * F+r B$ can be rewritten $z$ * $N E+(r+q) * E$, where NE is non-human wealth and $E$ is human wealth. 20 Then, since $C-(d+p) \star w$, we have:

(18) $B-(r-d) * E+(r-d-p) * N E-I$

Now, bring I to the LHS of (18), and use (16) to write:

(19) $W-(r-d) * E+(I \cdot d \cdot p) * N E$

Finally, define ne $-\mathrm{NE}-\overline{\mathrm{NE}}$, where $\overline{\mathrm{NE}}$ is the steady-state value of NE. Then, since $E$ is constant in (19), and since $W-E+N E$, we can re-write (19) 
as :

(20) ne $-(d+p-r) *$ ne

At any instant, the housing arket must clear. Since there are no costs of adfustment in housing investment the housing stock can change discretely at any instant in order to maintain housing market equilibrium. This discrete change should be thought of as a very sharp, short-term housing boom; one which would be spread out over time in the presence of costs of adjustment to housing investment. Market clearing in housing requires that $P_{H} * H-s_{H}$ * $(d+p) * W$. Moreover, $P_{H}=I * q_{H}, q_{H}-u+v * q_{F}$ and $H-K / u$, so chat market clearing in housing requires that:

(21) $K-\left[u \star s_{H} \star(d+p) \star w\right] /\left[u+v \star q_{F}\right]$

At the moment of a policy change, both $w$ and $q_{F}$ fall, and the Instantaneouse -ffect on housing demand is indeterminate. On the one hand, wealth falls, depressing housing demand. On the other hand, the price of housing falls. For a small change in $q_{F}$ a simple calculation establishes the following proposition:

The demand for housing rises (falls) on impact as long as the

initial value share of land costs in total housing exceeds (is less than) the Initial share of land wealth in total wealth.

The condition for a rise in housing demand upon a fall in $q_{F}$ is almost surely satisfied, since actual dats suggests that the share of land costs in housing appears to be well above the share of land wealth in cotal wealth (including 
buman wealth). Note that in long-run equilibriun, $K$ must rise after a fall in $q_{F}$ since the numerator. In (21) returns to its pre-policy change level (1.e. $W$ recovers to its initial value) while $q_{F}$ in the denominator is permanently reduced.

At the moment of the policy change, the housing capital stock changes discretely in the amount $d\left(K_{0}\right)$. How is this discrete change in $H$ financed? The answer 1s: foreign borrowing, 1.e. the country runs an instantaneous current account deficit to finance the Jump in $K$ at the moment of the policy change. In perticular, he have:

(22) $d\left(B_{0}\right)=d\left(K_{0}\right)$

Along the path of adjustment, wealth rises, and according to (21) so does $K$. The adjustment path is one of rising $K, B$, and overall non-human wealth, NE. 21

We can now finally put the pleces of the dynamics together. Consider the effects of a trade liberalization that reduces $P_{F}$ from a high, autarky level to the lower world level. On impact $q_{F}$ falls, and so therefore does overall wealth. ne, which measures the gap between NE and its steady state value, becomes negative. Also, the demand for housing rises instantaneously because of the fall in land costs, and so the housing capital stock jumps discretely at the moment of impact, with the investment boom being financed by foreign borrowing. Over time, non-human wealth NE recovers to 1ts long-run level, as the economy runs current account surpluses, and accumulates net foreign claims B. In the long run, B rises above its initial value. Along this path of 
current account surpluses and rising wealth, the housing stock also rises, according to (21):

\section{Some Spatial Considerations}

Our model certainly overpredicts the wealth effects of a change in food prices, since land is treated homogeneously, and ald land in the economy, whether in an agricultural district or in the Ginza, is assumed to fall in the same proportion. In fact, the value of land in advantageous locations will command a market price above the price available in agriculture, and the proportlonate drop in land values will be less than for agricultural land. In this section we talk about some of the implications of introducing locational rents as a way to relax the unsatisfactory assumption of howogeneous land.

Consider the following elementary extension of the model. Suppose that proportion $n$ of the population lives in the central city, and proportion 1 $n$ lives in the outside of the clty. All farm land is in the outside of the c1ty as we11. For the moment, suppose that because of the capacity of public amenities, the placement of job sites, tc, there is no migration of households between the two zones, so that the proportions $n$ and 1 - $n$ are fixed. The two regions differ only in terms of land availability. In the city, land is fixed at $L^{C}$ and is used entirely in housing, $L_{H}$, while in the outskirts, total $L$ is equal to $L^{0}-L_{H}{ }^{0}+L_{F}$ Urban land is scarce, so that the man-land ratio is much higher than in the outside of the city: $n / L^{C} \gg(1-n) / L^{O}$. For all of the equilibria that we will look at, we will also assume that $\mathrm{n} / \mathrm{L}^{\mathrm{C}}>(1-\mathrm{n}) / \mathrm{L}_{\mathrm{H}}{ }^{\mathrm{C}}$.

Aside from location, all households have identical tastes. In particular, 
they allocate an equal share of their consumption to housirig. Under these assumptions, the fand price in the city will of course be higher than the land price in the outside of the city. In parcicular, $p_{H}{ }^{-}-n *(d+p) * 4$ $\left\langle L^{C}, v\right\rangle$, and $\mathrm{p}_{\mathrm{H}}^{\mathrm{O}}=(1-n) *(\mathrm{~d}+\mathrm{p}) * \mathrm{~W} /\left(\mathrm{L}_{\mathrm{H}}{ }^{0} / v\right)$, whth $\mathrm{p}_{\mathrm{H}} \mathrm{C}>\mathrm{p}_{\mathrm{H}}^{\mathrm{O}}$. In the outskirts, we have $\mathrm{F}_{H}{ }^{\mathrm{O}}-u * I+\mathrm{u} * \mathrm{q}_{\mathrm{F}}$, where $\mathrm{q}_{F}$ is the value of a unit of land in agriculture. Note that wen $q_{F}$ chenges, say because of iberalization in trade, only in the outskizts of the clty will the price of housing change.

It can easily be checked that al of the earlier conclusions w1 stili apply concerning the constancy of the ratios of $Q$ to all of the forms of wealth. The magnitude of the weath effects of the policy change will now be considerably saller, however, because only $(1-n)$ proportion of the population w11 experience fall in land prices, and a consequent reduction in hous ing prices.

Now suppose that there is free mobility across the two regions. Suppose that the urban center is preferred because of amenities (e.g. schools, social services, public eransport, etc.). The population wili sort 1tself out until individuals are indifferent to living in the two reglons. This wil occur when the costs of housing in the urban center are sufficiently above the costs in the outskirts to compensate for the difference in amenities. Now, when agricultural land prices change, land prices both in the c1ty and the outskirts w11l change, because lower land prices in the periphery will induce out-migration from the center, thereby relieving demand for the scare urban land. It is still probably the case, however, that the proportionate decline in land prices in the outskirts wil be higher, and perhaps significantly so, than the 
proportionate decline in land prices in the center.

Section 5. Structural Change and the Balance of Payments in A Dynamic MultiSectoral Simulation Model

In this section, we attempt to take a step toward empirical implementation of the preceeding model by specifying a more appropriate multi-sectoral simulation model of the Japanese econony. The exercises in this section are still not true "empirical" estimates in the normal sense, however, for two reasons First, the model ltself is in a very prelimary form (we offer it here as a spur to research more than an lllustration of finished researchy. While we still rather crude attempt to calibrate the model to mimic the Japanese economy, we do not make econometric estimates of the key behavioral relations in the model, but rather make "guesstimates" of parameter values. These guesses must be subjected to statstical scrutiny in later work:

The model that we will describe takes as given the values of key variables in the international economy, especially U.S. interest rates and the levels of output in the U.S., Europe and the developing countries. We are planning in the near future to integrate this model into the multi-country simulation model that we discussed at the beginning of the paper, both to study the effects of forelgn policies on Japan, as well as to allow for the effects of Japanese policy on international variables such as U.S.-dollar interest rates.

The model is described in some detail in the appendix. It is a five-sector model of the Japanese economy, focussing on: food, manufacturing, services, durables, and construction. The "durables" sector is a sector that produces 
equipment capital for investment, as well as non-housing consumer durables for households. The manufacturing sector includes all manfacturing except that which is produced by the durable goods sector. These sectors each use primary inputs (captsal and labor, and land in the case of food and construction) to produce value added, which is then combined with inputs of the other sectors, and with imported intermediate inputs, to produce final outputs. In addition, the agriculture sector and the housing sector use land in producing value added.

An input-output structure among the sectors is specifled, with the input requirements depending on relative prices in the economy. The input-output structure works as follow. All sectors use manufacturing and services as interpediate inputs, whlle food, durables, and construction are not Intermediate inputs into the other sectors. The durabies sector, as just indicated, produces the good used for equipment investment throughout the economy, as well as the non-housing durables for households. The construction sector produces physical capital for housing, and physical capital for nonresidential structures.

The housing sector is specifled slightly differentiy from the preceeding theoretical model, though whout important economic effect. In the simulation model, owners of housing physical capital do not own the land under their buildings. Rather, they rent the land each period, at the same rental rate as the land in agriculture. Since the discounced value of those rents is equal to the value of unft of land, the owners of housing are indifferent to paying a per-period rental (as in this model) or to owning the land, as in the theoretical model of the previous section.

Empirically, we allow for heterogeneity in land holdings by assuming that 
land in the urbar centers is a fixed constant price above the price of land at the periphery (where the agriculturehousing margin is shifting). Thus, when agricultural land values decline, so to do urban land prices, by the same absolute amount (and obviously, by a smallez proportionate amount). In the calibration of the model, we assume that urban land not at the margin of substitution averages approximately three times the value of agrlcultural land.

Each of the sectors is assumed to be perfectly competitive. With valuemaximizing floms. In each pertod, the capltal stock in the sector is given, though labor may flow freely across the sectors in each period. Thus the wage is equalized across sectors and frictional employment problems resulting from sectoral changes are ignored at this point. The nominal wage is set one perlod in advance, at a level that in expectation will be compatible with full employment. Thus, in the absence of a contemporaneous unexpected disturbance, employment wil always be at the full-employment level. This specteication is made to reflect the high degree of flexibility of Japanese labor costs in response to disturbances in the economy, though the assumed flexibility is perhaps too extreme in the current version.

Firms make investment decisions subject to convex costs of adjustment in the firm's capital stock, along the lines of Hayashi (1982). This makes the firm's investment decision a function of Tobln's $q$, which is the ratio of the firw's equity value to the replacement cost of capital. In this now-familiat specification, shocks to the sector which increase current and future profitability lead to a rise in Tobin's q, which may be thought of as the discounted value of future marginal products of capital, divided by the replacement cost of capital. The rise in Tobin's $q$ then induces an 
accumulation of capital in the sector. Over time, as the capital stock increases, there is a deciline in the marginal product of capital today and in the future. Tob1n's q falls, and the investment boom subsides.

The fact that firms make investment decisions based on rational expectations of the entire time path of future profitability sets this model apart from standard CCE models, which typleally specify myopic investment behavior. Sachs has assumed dynamic investment optimization in severa! eablier simulation todels, such as in Lipton and Sachs (1983) and dynamic wodels of Mckibbln and Sachs. Most of those earlier models focussed, however, on the interaction of several one-sector economies. A recent extension of the Tobin's q approach to a one-country motel with a wult-sectoral economy is Goulder and Sumers (1986), who use the approach to study the effects of U.S. tax code changes on U.S. Investment. The present paper is close in spirit to that of Goulder and sumers, though unlike the coulder and sumers study, our model is a monetary model, and allows for a fuli linkage of the economy to international trade and capital markets.

He assume that the aconomy is completely open to inernational movements of capital, and that domestic and foreign assets gre perfect substitutes, in the sense that expected yields on yen and dollat (f.e. inteinational) assets are equalized period to period. The world interest rate in dollars is fixed, so that the period-to-period expected return on domestic assets, when expressed in dollars (i.e. When correted for expected changes in the exchange rate), is. fixed at the international level. All domestic assets are also considered to be perfect substitutes among themselves. Thus, the financial yields on land, housing, domestic equities in each sector, government bonds, and foreign bonds, all have the same ex ante returis in every period. Household 
behavior is along the Ines of Blanchard(1985), as described in the previous section. Households with a random time horizon, and a Eixed probability of death each pertod, make optimizing intertemporal consumption decisions. Once the total amoune of consumption each period is decided upon, the consumption spending is allocated to several Elnal goods according to a Cobb-Douglas utilty function. Thus, the share of consumption allocated to the various consumption goods is fixed. The consumption goods are: food, housing, other consumer durables, other consumer non-durables. The ocher consumer nondurables include domestic goods as well as imported final goods.

Consumer durables are handled in a special way, deserving separate note. We assume that chere is a separate consumer durables industry that rents consumer durables (which we define to include housing and all other durables) to the household sector. The supply of durables thus depends on the investment decistons of the durables sector, and the rental rates on consumer durables clear the durables markat period to period.

The model is specified in non-linear form, and then numerically linearized around an initial equilibrium. Certain variables are linearized in the levels (generally, output quantities), whlle other variables are linearized in the logs (in most part, wages, prices, and the exchange rate). This strategy is followed for computational purposes. The linearization helps us to solve efficiently for the rational expectations path of the economy, as well as to calculate optimal policy rules given a prespecified intertemporal quadratic loss function for the economy (However, we do not compute any optimal policy rules in this paper.)

To sumarize, the model is an elaborated computable general equilibrium (CGE) models of the Japanese economy, with several features that set it apart 
from standard CGE models. First, and most important, it is truly dynamic, with firms and households making dynamic savings and investment decisions based on rational expectations of the future economic environment. In contrast, most CGE models have static decision functions for savings and investment. Second, it gives spectal focus to the nexus of land in housing and agricultural production, which is the focus of our analysis.

\section{Simulation Results}

At this preliminary stage of investigating and caibrating the model, we present only two simulations. The experiment is a ilberalization of food impores (as noted earlier, experiments involving land tax changes might be more relevant for the current policy discussions; we wil pursue these other simulations in later work). We ssume that domestic food prices are 50 percent above world levels, and are kept there by a fuily prohibitive tartef. The tartfe 15 then removed instantly and permanentiy in the first year of the stmulation. We study two cases of the Blanchard model: $p=01$ fexpected time horizon -100 years) and $p=.05$ (expected time hortzon - 20 years).

Consider the longer time hortzon first, as show in Table 3 . As soon as food imports are liberalized, the price of food in nominal Yen terms falls by 38 percent, whlle the Yen exchange rate depreciates by 13.4 percent. (The overall effect is a decline in $\$$ prices of 50 percent). Land wealth falls by 38 percent of GNP, and totul wealth falls by 29.6 percent of GNF. Since the change in consumption is (d $+p$ ) times the change in wealth, with $d m .05$ and $p^{-0.01}$, we find a change in consumption of 1.78 percent of GNF: Because of the fall in land prices, value added in agriculture falls by 0.91 percent of GNP. As the housing capital stock rises, further encroaching on land utilization in 
- ante

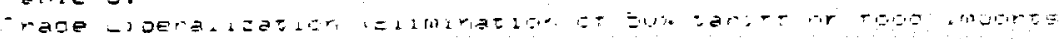

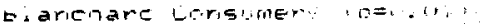

jagariese EC:Huriv

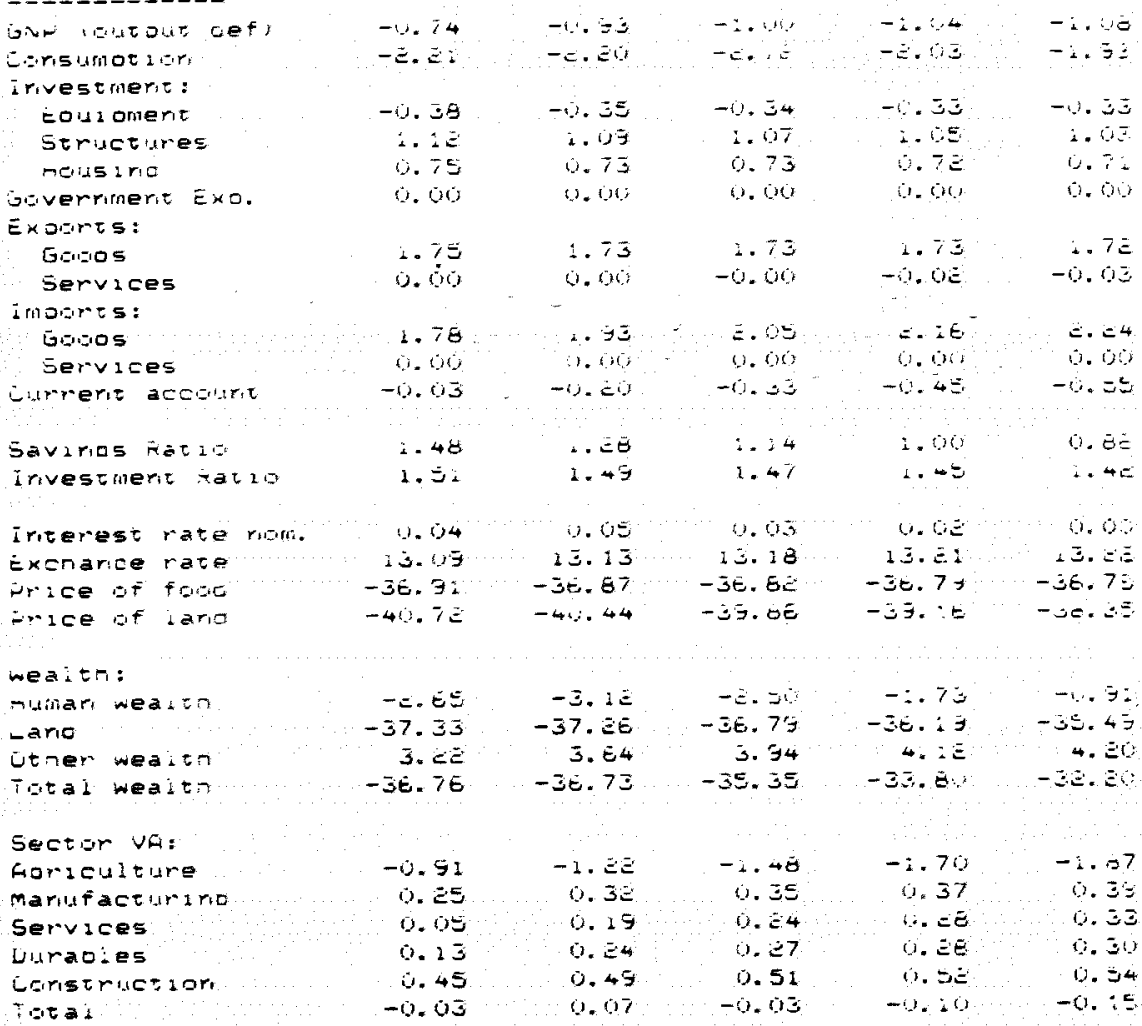


Notes to tables:

1) All variables unless otherwise stated are recorded as deviations from baseline measured in percentage units of GNP.Nominal values have been deflated by the gross output deflator. All prices and exchange races are recorded as percentage deviation from baseline. Interest rates show deviations of percentage values. Value added is shown as deviation from baseline of actual quanticies in percentage units of oNP. 
agriculture, the agricultural output falls further, reaching decline of 1.84 percent of GNP by the fifth year.

The decline in consumption causes savings to rise, In this case by 1.11 percent of GNP. At the same time; though, there is a significant increase in structures investment, both in housing and in non-residential structures. The overall investment ratio rises by 1.09 percent of GNP in the first year, and remains at 1.11 percent of GNP above baseline for the following few years. Note that the savings rate begins to fall in the second year, so that the rise In investrent exceeds the rise in savings. thereby sending the current account Into deficit. By the third year, the current account deflcle is about 0.3 percent of GNP relative to the baseline, and by the fifth year the current account deficlt is about 0.5 percent of GNP relative to the baseline.

Unlike the theoretical model, there is no one-time boom in housing or structures. Because the construction industry is only about 10 percent of GNP, the rise in structures investment of about 1.4 percent of GNP is a significant Increase in output in the industry, which stralns its capacity, causing the Investment boom to be spread out for several years.

Finaliy, notice the sectoral distribution of output in the years following the shock. Naturally, the agricultural sector is the big loser, with a very sharp drop in output. All other sectors show some increase in output, with construction showing the blggest gain in value added originating.

The simulation in Table 4 carries out the same exercise but with shorterlived households, We expect from the theoretical discussion that the wealth effect of the land decline will hit consumption harder in this case, with the result that the rise in savings should be larger. In fact, there is now a 1.7 percent of GNP Increase in the savings rate in the year of the shock, which 


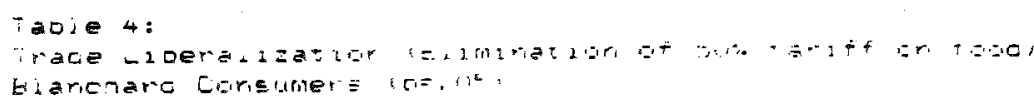

Iabariese Ecbrim

Gin- lateolit aet।

Lirislunoe 2 iri

ipivestinert:

E 0 LI DHert

Strictires

$\rightarrow r .452 r i d$

strveprinert: Exo.

Exomts:

$$
\text { Goisos }
$$

Services

zmares:

Genges

Services

Lurrerit aceilut

Savirios Fatir

I pivestmerie Rat 10

interest rate nom.

Exenarioe pate

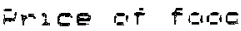

सr:CE gf izro

Wez:

mingri wez.tn

ince

wrner wea!ch

graj hiealen

EgCtGr $\forall A:$

goricuiture

marufaet i. 2 ric

Services

iburates

Eorstruetinis

Tढच

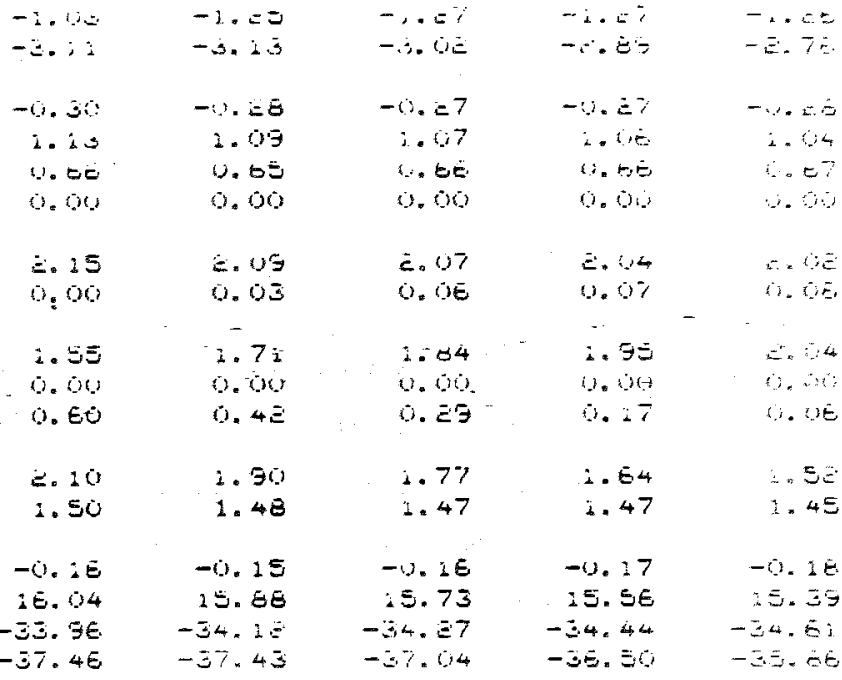

$-6.71$

$-34.55$

4. 14

$-1.63$

$-i, 57$

$-\dot{i} .5 e$

$-3.44$

$-34.73$

$-34.53$

$-\overline{3} \cdot 3 i$

$-3.3 .3$

こ. 85

ㄴ. 0

7.25

$-3 i \cdot 38$

$-30.18$

$-36.3:$

$-27.6:$

$$
\begin{array}{r}
-0.84 \\
0.36 \\
-0.05 \\
0.30 \\
0.44 \\
0.02
\end{array}
$$$$
-1.24
$$$$
-2.40
$$

6. 35

0.05

0.35

0.47

$0.0 E$

0.5

$-5 \cdot \theta=$

$-2.76$

6.35

$\therefore 27$

द. 3

0.35

a.: 4

0.36

0.55

\% 5

- $0.2:$ 
now signiflcantly exceeds the investment bulldup. The current account thereby moves 1nto surplus. Note, Importantly, that the s1ze of the Investment boom is very close to the earlier simulation. The Blanchard parameter $p$ does not Importantly affect the speed or size of the investment buildup, only the size of the decline in consumption following the fall in land prices.

Section 6. Conclusions and Extensions

The taking-off point for this paper is the current Japanese policy goal of stimulating domestic demand. That policy aim has several motivations: (1) to counteract contractionary effects of a shift in the U.S policy aix cowards fiscal contraction and monetary ease, (2) to reduce Japan's trade surplus in order to reduce protectionist pressures in the rest of the world, and (3) to rectify distortions in the Japanese economy that give advantage to foreign investment over domestic housing investment. We argued in Section 2 of this paper the Keynesian case (argunent 1) for a policy-led demand expansion is rather weak emplzically and theoretically. The shife in the U.S. policy mix is unlikely to have highly deflationary consequences for the Japanese economy; indeed the changes could well be expansionary. We also noted, however, that even with a substantial shift in the U.S. policy mix, Japan's external surpluses were likely to remain large. Therefore, if there is indeed a pressing case for reducing those surpluses, further policy actions would likely be necessary. We pointed out two actions that would almost surely be effective, though perhaps at high cost: a return to the large budget deficits of the late 1970s, and a return to capital controls. The unattractiveness of these measures has led policymakers to consider additional ways to spur 
private investment, particularly housing investment.

These possible measures, involving changes in lard-use policy, are the focus of sections 3 and 4 of the paper. Several kinds of polfcy measures were considered: (1) trade liberalization in foodstuffs; (2) changes in zoning ordinances; and (3) changes in the tax treatment of agricultural and housing real estate. We introduced a theoretical model to study the interactions of land, savings, and investment. The purpose of this model was to emphasize a number of linkages wich are particular to Japan, and could have important implications for the effects of policy upon the Japanese economy. The key point from this discussion is that these policies have effects both on investment and savings, often with indeterminate signs. In general, poiticies that reduce agricultural land values zend to raise savings, the external surplus, and the net foreign investment position, while at the same time such polictes tend to raise housing inveswent, thereby lowering the externel surplus and the net foreign investment position. In the models that we studied, the houstng effect is necessarbiy short-lived. In the long run, the savings effects downate. Most of the policies considered that would contribute to a short run housing boom would also lead to current account surpluses in the longer term, and an actual increase in the economy's net foreign asset position. We emphasize that these results are derived from a highly stylized model of the Japanese economy, and that more definitive results could only be obtained by carefully examining the other important Inkages which we have discussed above, but have not chosen to focus on in this paper.

A multi-sectoral simulation model was then introduced, to begin the process of quantifying some of these effects. We stressed the rudimentary nature of 
the empirical estimates, but presented them both to give an order of magnitude and to encourage furcher empirical investigation of these issues, we noted that the size of the current account effects from the polfcy changes depends importantiy on the nature of intertemporal consumption behavior. The more short-lived are the horizons of households, the more likely it is that a reduction of land prices would produce a rise in the external surplus, rachez than the fall that is goal of the policy.

Let us conclude wth several observations about the research agenda in this area. In our view, it w11 be fruttelul to proceed with a more careful quantification and spectication of a model like that presented in section 4. Most Importantly, we need to broaden the scope of our theoretical work in order to determine the relative importance of the varlous tax and trade policies in maintaining the high price of land. In empirical work, much more information must be included about the patterns of land use in Japan, and the technical tradeoffs between alcernative uses of land Even rudimentary information such as the average ratios of land to flxed capical in various uses should be investigated more fully. Also, the response of that ratio to relative price changes should be examined econometrically.

It should be possible to test directly for the effects of land prices on the cost of housing and on the demand for housing. Moreover, the links of land prices to agricultural policies could also be studied fruitfully. The extraordinary premium of rice prices above world market levels is a relatively recent phenomenon, dating back to the late 1960 s, when the regulations involving price maintenance for rice were changed. From the early 1960 s to the late 1960 s the premium of the domestic price of rice over the import price of rice rose from about 20 percent to more than 100 percent. 22 It should be 
possible to study the effect of this policy change on contemporaneous land pricos and land use patterns. Another area where quantification is importantly needed is on the effects of tax policies on land allocation decisions. Lietie seems to be known rigorously about the overall effective tax rates on the different uses of land.

The model has so far neglected various potentially important inkages of housing investment with other forms of spending, that could significantiy afect the quantitative ostimates. Varlous kinds of consumer durabies axpandtures, such on furnfture and household appifsnces, are complementary with housing investment. It is widely believed that Japan's relatively low stock of housing relative to income is matched by a low supply of other consumer durables relative to income. Indeed, an important reason for the difference in U.S. and Japanese household savings rates is the fact that American households save wuch larger share of income in the form of consumer durabies (which typically gecs counted as part of consumption rather than savings). To the extent that decrease in land prices stimulates housing derand, it is Itkely that it would also stimulate the demand for other consumer durables, thereby lncreasing the likl1hood in the short run of a significant reduction in the external surplus. Similarly, one presumes that many forms of public investment spending (e.g. on sewage and roads) should also rise in tander th a housing boom. Thes complementarity effects in private demand can be investigatod through empirical estimation of consumer demand systems.

A further major area for empirical investigation is the fiscal implications of the land-use policies. The current policies of high internal price support for food, for example, have large direct budgetary consequences. A reduction 
of such price supports would not only lower internal land prices but also free up government resources for public investment spending. (In our theoretical model, we assumed that reduction in subsidies $s$ were macched by reductions in taxes $T$; alternatively we could have allowed for reductions in s to finance Increases in public sector investment). Similarly, land sales by the government would probably reap enormous revenues, that could also provide the fiscal base for higher public investment spending.

An loportant theoretical area that should be investigated further involves the welfare and distributional implications of alternative pollcy changes One of the motivations for many of the proposed changes in land-use policy is the current market distortion agatnst housing investment. How large are the welfare costs of such distortions, and how would the welfare of different generations and different sectors be affectod by elimination of those distortions? 


\section{Iist of References}

Artle, R., and Pravin Varalya. "If fe Cylce Consumption and Home Ownership", Journal of Economic Theory, Vol. 18, 1978, pp. 38-57

Bergsten, C. Fred, and H. R, Cline. "The United States - Japan Economic Problem", Institute for International Econowics, Policy Analyses in Internationai Economics, No. 13, October 1985

Blanchard, 0 . "Debt; Deficits and Finite Horizons", Journal of Political Economy, Vol. 92 , No. 2, 1985 , pp. 223-247

Economist. "Jepan Survey", December 5, 1987

Goulder, L.H. and Lawrence H. Sumers. "Tax Polfcy, Asset Prices and Growth: A General Equilibrium Analysis," NBER Working Paper No, 2128, January 1987

Hayami, Y. "Rice Policy in Japan's Economic Development", American Jourral of AgEleul tural Economics, Vol. 54, 1972, PP. I9-31

Hayasht, F., T. Ito, and J. Slewrod, "housing Finance Imperfections and Private Savings: A Comparative Simulation Analysis of the U.S. and Japan, NBER Working Paper No 2272, June 1987

Maekaws Comission (Special Comittee on Economic Restructuring). Interim Report. December I, 1986

Martis, S. "Deficlts and the Dollar Revisiced". Institute for International Economics, Polfcy Analyses in Internatonal Economics, No. 14, August 1987

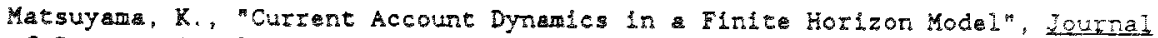
of International Economics, November 1987, PP. $299-314$

Ohmse, K. Bevend National Borders. Homewood, Il11nots: Dow-Jones Irwin, 1987

Okita Comission (Advisory Comittee for External Economic Issues). Report of the Commictee, Apri1 3, 1985

Otsuka, K. and Y. Hayam, "Rice Policy in Japan," American Journal of

Agticultural Economiss, vol. 67, No. 3, August 1985, Pp. 529.538

Oudiz, G. and Jeffrey Sachs, Macroeconomic Bolicy Coordination among the Industrial Economfes", Brookings Psoers on Economic Activity, 1:1984

Sachs, J. and N. Roubini, "Sources of Macroeconomic Imbalances: A Simulation Approach", presented at the Third International Conference of the Institute for Monetary and Economic Studies, Bank of Japan, Tokyo, June 1987, and NBER Norking Paper No, 2339, August 1987.

Takenaka, $H$, and $N$. Ishii, "Simulation of Policy Coordination under Structural 
Adjustment: An estimate of the Economic Impact of the Maekawa Report" "mimeo, Ministry of Finance, May 1987

Yoshitom1, M. "comment" in Lapan and the United States Today: Exchange

Rates Macroeconomic Polfcles, and Elnancial Market Innovation. edited by Hugh T. Patrick and Ryulchiro Tachi, New York Center on Japanese Economy and Business, Columbla Unlversity, 1986 
Table 2. Value of Land and Structures in Japan and the United States, end1984, \$bilion (calculated at Y25I - \$1)

Japan

Velue of Land

3690

317

- as percent

of GNP

- ss percent

of net worth

value of Farm land

as percent of total

land

Value of Residential

Structures

- as percent

of GNP

- es percent

of net worth

Value of Non-Residential

Structures

- as percent

of GNP

- as percent

of net worth

Percent of Non-Fara

Land Value in Total Value

of Structures

Memo I tems :

GNP

Net Worth

71231
United states

79

24

18

3308

90

27

1902

52

26 
a For Japan, the measure is the ratio of the value of "land under buildings" divided by the sum of the land value and the net fixed capital stock in structures. For the U.S., the measure is the value of non-farm land divided by the sum of the value of non-farm land and the net fixed capital stock in structures.

Sources: For Japan, "Closing Stocks of Assets and Liabilities by

Inst1tutional Sector (1982-1984)", Statist1ca: Yearbook of Japan. 1985, p. 563. For the U.S., "Balance Sheets for the U.S. Economy, 1947-86, Board of Governors of the Federal Reserve System. May 1987; and "Sumary of Fixed Reproducible Tangtble Wealth Series, 1925-86\%, in Survey of Curtent Bustness. November 1987, p. 36 
1. See for example M. Yoshitom (1986).

2. Bergsten and Cline contended in late 1985 that "Japan, as the second largest economy in the world and perhaps the major beneflciary of an open trading system, must alter its flscal policy substantially and go the extra mile to deal with the criticisms so widely leveled against lts trade policies." See Bergsten, C. F. and W, R. Cline. "The United States - Japan Economic Problem". Institute for International Economics, No. 13, October 1985, P. 129. More recently, Marrls has argued for a Japanese fiscal expansion: "Europe and Japan have not yet taken expansionary fiscal policy action on the scale needed to offset the inevitable negative drag on theit growth as the US trade deficle is eliminsted." In Marris, S. "Deficits and the Dollar Revisited". Institute of International Economics, August 1987, p. 39.

3. The role of structural policy measures, especialiy in the area of land wse, has been a major point of emphasis in several important commissions in Japan, including the Okita Advisory Comittee for External Economic Relations, Aptil 1985, and the two reports of the Makawa Comission.

4. According to OECD estimates, the 1987 fiscal expansion amounted to approximately 0.3 percent of GNF rise in the structural deficit in Japan. Some commentators have attributed Japan's recent rise in domestic demand to this modest stimulus. In our view, of the explanation lies in: (1) falling real interest rates; (2) rising household yealth; (3) the terms of trade improvement in Japan following the 1986 deciline in oll prices, which only recontly have been pased on to consumers.

5. This calculation is based on the assumption that Japan pegs the money supply, and not the interest rate. The U.S. poifcy ix causes Japanese shorttera interest rates to fall. If Japen instead pegged the interest race, it wight choose to reduce the money suppiy in response to the U.S. poilicy measures, and this could turn the midly stimulative effect into a isildy contractionary effect.

6. The U.S. number probably overstates the land share of value, since the 31 percent is estinated as the cotal value of non-fam land in the U.S. divided by the sum of this value plus the value of net structures. Some of the land counted in this ratio probably includes land that is not assoclated with structures. The 35 percent estimate is taken from a study of Hayashi. Ito, and Slemrod (1987), who cite a 1982 survey of the ministry of construction.

\section{Cited in The Economist, "Japan Survey", December 5, 1987, p. 31}

8. To the extent that lant and government bonds are highly substitutable financial assets in private portfollos, and to the extent that government purcahses of land have little affect upon the price of land, a bond-financed purchase of land would have little effect on aggregate demand. 
9. The price of housing land in Tokyo rose by about 95 in 1987, prompting protests at the Bank of Japan's low interest rate policles, which were accused of fueling land speculation. In all of Japan, land prices rose only by about 78, however. (Data from the Economist, December 5, 1987)

10. See the Economist, "Japan Survey," December 5, 1987.

11. From personal correspondence with Mitsuhiro Fukac, Bank of Japan. The majority of the remaining land ( 67 of total area) is covered by forests.

12. Roughly 10 of the labot force is reported to be employed in agriculcure. a much higher number than in other $O E C D$ countries, though part of the discrepancy is due to the large number of Japanese whom report they are parttime farmets 1 ri order to take advantage of certain fiscal benefits.

13. The 1nterim report of the Mekawa Compission aade the following observations: "2.4.1: The Enhancement of housing and soclal stock crucially. hinges upon the solution of land problems, in particuler, the promotion of land supply 1s indispensable. 2.4.2 there Is an urgent need to undertake far-reaching measures in large urban areas tri order to ensure the promotion of the orderly supply of houslrg. land and the stablilty of land prices..2.4.3. In so dolng, it is recessary to fmplement specific polictes with spectal acentlot to: a. the redistribution of space le g. easing regulations and restrietions regarding the landf1ll reclamation of public waters, promoting the conversion of paddy land to other uses in urbamzation promotion areas: and reviewing zoning regulations), $b$. the 1rtensive use of land (e.g easing regulations regarding on total floor space and promoting urban redevelopment work to et the need for nore offlces and other comercial sites); $c$. the greater use of unused or under utlized sizes (e.g. promoting the wore offictent us of goverusent and corporate-owed itas and encouraging the conversion of abandoned plant sites to housing stes), d. the utilization of new wodalities of housing land supply (e.g. Formulas allowing joint-use with the landowner, including land trust formulas and tenanoy formulas), te. the utilization of tax policy to promote the supply of housing land (e.g. strengthening the aplicetion of taxation on gricultural land ln urbanization promotion areas to motopproximate tax rate on residential land), and $F$. the stablilzation of land prices (6.g. Ut1lizing the National Land Use Planging Act and levying higher tax rates on very shore-tera real estate trading).

Quoted frow the Interim Report, Speclal Commttee on Econonic Restructuring (Chairman: Haruo Maekawa), December 1, 1986

14. One interesting preliminary attempt to quantify the potentlal effects of the Maekawa Comasion recomendations is Takenaka and Ishil (1987). Th1s otherwise informative scudy does not, hovever, attempt to explain the precise aconomic channels through which the Maekawa recomendations would operate.

15. It 1s useful to alke small polnt about the pol1tical economy of land use in Japan. There are Important and well known pol1tical explanations for the current land use policles in place. The ruling Liberal Democratic Parcy 1s has long derlved Important support frow rural areas, whlch are disproportlonately represented In the Japanese Diet. Agricultural groups 
contribute heavily to political campaign, and spend considerable sums in political lobbying. Many of the pollcy changes that we 111 conslder would be difficult to carry out policically. Our focus in this paper is on the economic implications of various possible policy changes, and not on the likl1hood of their implementation.

16. Throughout the paper we ssume that individuals are ble to "pierce the corporate and fiscal ve11". Given that a large anount of land in Tokyo, and elsewhere in japan, is owned by the corporate and public sector, we are assuming that the fall in these land values wll be reflected in stock prices and future tax $11 a b 11$ ties, and individuals 11 fully perceive these changes in total wealth.

17. See Matsuyama, $\mathrm{K}$. "Curgent Account Dynamics in a Finite Horizon Model, * joubnal of International Economiss. November 1987 , Pp. 299-314, for Further detals on the oper-economy version of the Blanchard nodel.

18. In simple economy where expenditure shares remain constant, i. e. a cas where consumer demo functions are Cobb-Douglas, and where the 11 quidity constraint requifes that agents pay fixed proportion of the cotal cost of a house as down payment, then the steady-stete expendicure on housing would not change as long as steady-atate income did not change. If the pollcy considered had no effect upon the nacure of the ilquidity constrint in the housing warket, than, in model such as ours, the steady-state level of ggregate wealth in the conomy would be unaffected.

19. We asume throughout the text that the oqulibriu in an tntsior solution where some land is used in the gricultural sector so that the marginal product land is determined by the price of food.

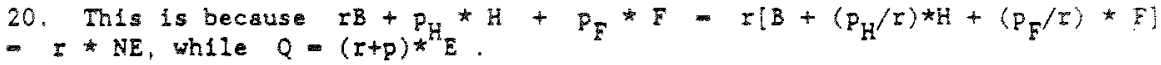

21. Note that from (16) and (21):

$$
\dot{K}=\left[u * s_{H} *(d+p)\right](\dot{K}+\dot{8}) /\left\{u+v * q_{F}\right)
$$

The for: that:

$$
\dot{K}=n * \dot{B} \text { wher } r=\left[u * s_{H} *(d+p)\right] /\left[u+v * q_{F}-u * s_{H} *(d+p)\right]
$$

It is easy to show that the denominator in the RHS of the expression for $n$ is positive. Therefore, since the change fn $W$ is equal to sum of the changes in $x$ and $B$, wave :

$$
\dot{k}=[n /(1+n)] \dot{w}
$$


B $-(1 /(1+n)] \dot{W}$

22. For an excellent discussion of the polltics and economics of Japanese rice pollcies historlcally until 1980 . see the studies by Haymi (1972), and Orsuka and Hayam (1985). 


\section{Appendid 1 \\ Jepen Yuzte-Sectorel Kode1}

The simulation model described here is dynamic, muti-sectoral CGE model of the Japanese economy. The structure of the model is similar to the Mckibbon-Sachs globel model: all qents are ratfonal and decisions sre made with perfect foresight based upon intertemporal meximization of utility and profit functions. A major advantage of this model over other CGE models is that resources are allocated among sectors by forward-looking, profit. maximizing firrs. Thus it is well suted for the andysis of the impact of vartous types of tax policy changes upon the Iagarase econony.

There are flve produced goods, Including two types of captral inpits, and qive consumption goods. The consumpton goods are purchased by individuals, the government, and forelgners. Capital goods are used for investment and are exported. Two non-produced goods, energy and raw materials, are imported along. whth other producer inputs and consumption goods.

Frivate consumption is determined by representative agent's maximization of a utility function. Intertempoxal consumption is bllocated accoring to standard additively separable utily functions with the utility level each period given by a log uthity function. This impiles that total consumpton each period will equal the consumer's zate of time preference (plus an adjustone for mortailty) whalplied by cotal wealth. The within-period allocataion of consumption among goods is determined by a Cobb-Douglas utility funceion. There are five goods and services bought by consumers: sarvices: food, housing, other durables and ocher non-durables. The tro consuret durables, housing and other durables, are assumed to provide service flows in proportion to the exiscirig captal stocks. In both cases the goods are rented each period, and there are no adustwent costs to households in changing their rentals. Investment denand for housing, structures and equipment is determined from Tobin's q-equations in the supply-side of the model as described below. The government purchases goods and services directy from each producing sector, and may also hire labour and import goods. Governwent expenditures are assumed to be a fixed, exogenous share of Japanese GNP. AII fmported goods apart frow food are assumed to be fraperfect substitutes 
domestic goods, and lmport shares of total consumpeion expenditures are determined using Cobb-Douglas utility functions. The demand for exports by forelgners is determined by demand equations with unitary price elasticites, and foreign expenditures on the Japanese good are assumed to be fixed in forelgn currency.

The supply-side of the model is structured similarly to an input-output table with each sector linked to other sectors through the purchases of intermediate inputs and captal. There are flve producing sectors sood, manufecturing, services, durables and construction, Each sector purchases manufactures and services as internedate inputs, and uses durables and the construction good tn order to intell equipment and bulld structures. Incermediate inputs can also be foported as zmperfect substitutes from abrodi. The value of import shares are calculated fron the production functions Al production functions have a nested Cobb-Douglaz fond, and each sector uses three non produced inputs: labour, raw waterlals and energy. The abricultural sector, as dicussed below, also useg land as non-produced input we assume

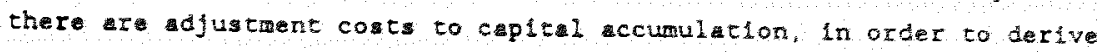
investaent demand equatlons, Tha lmplles that there wil be short-run supply constzints in each industry.

The construction of houshing snd etructures recelves special treatment 1 this model housing is assumed to be bulit using fixed proportions of land and the construction good. The arbltrage condition for housing construction requires that the cost of the input of lard and the construction good identically matches the discourted value of future rents on housing. The rental price of a house is deterwined by inverting the consumer's demand equation, and construction is assused to occur with a one-period lag supply constralnts upon the production of housing occur due to the upward sloping short-run supply curve in the construction fndustry. Structures are also assumed to combine a flxed proportion of land per unit of the construction good. Investment in structures in each industry is deternined using 9 equations which equate the present discounted values of the marginal product of structures with the discounted cost of the required rents on 1 and and payment for the construction good. It is important to recognize that for both Industries, the rise in lnvestment after a fall in land prices w1ll be directly related to the marginal input of land required with each additional unit of structures or housing. 
Wealth in this model consists of net human wealth (the present discounted value of wages minus lunp-sum taxes), equity in firms, the stock of housing, the stock of consumer durables, government bonds, the value of land and net foreign assets. All assets in the model are perfect substitutes and arbitrage equations determine their current values. Financial capital is assumed to be perfectly mobile across countries and the exchange rate adjusts so as to satisfy the interest arbitrage quation. The world rate of interest is exogenous.

In order to close the model, prices in each sector adjust so that aggregate supply equals aggregate demand. The werld price of imported inputs are assumed to be fixed in dolims, and the yen priees adjust wh the yenboliat exchange rate. The supply of labour ts exogenous, and contracts for nownal wages are signed such that the labour market clears, in expectation, one period ahead. Labour supply is perfectly elastic in the current period at the current nominal wage, so that contemporaneous unanticipated shocks will 3ffect current employment (though aploymant after the first year whll not affected). The rental price of land is determined as the marginal product of land in agriculture. The land usage in agxiculture is determined by subtracting land usage in housing frow tota land avaliable. All stock and werth veriables in the model are ajusted for current flows. The domestic nominal interest rate 1 s dererafned by fnverting a coldield money derand equation and setring the money supply as exogenous. In this version of the model, gl2 governonte spending is financed through bond issue and lump-sum taxes.

The equations of the model are non-1Inear. In order to solve the model He first linearize each equetion around steady-state values of the variables, and then using the techniques described in oudiz and sachs (1985) we solve for the unique stable ananifold. The conditions for stability of models can be checked numercaly. In pretice have found no difficulty with instability.

The infial parameterization of this version of the model was calculated using Japanese input-output tables and financial data from the Iapanese Statiscticel yearbook:1985. Modifications to the input output tables were ade in order to accomodate the structure of intermediate inputs in our inodel. Most notably, producer durables, and food are assumed to not be used as intermediat inputs in production. Likewise the addition of land as an input 
to housing and agriculture required that we adjust value added ln the relevant sectors accordingly. Each consumption good was assumed to be composed only of the good from the relevant producing sector. Thus, for example consunption of services was set equal to the total consumption expenditures on the services industry as reported in che linput-output table. The input-output table, the llocation of consuntion expendicures and wealth values are shown in Tables Al-A3. Appendlx 2 briefly outlines the behavloural equarions and permits the reader to examine the intial paranterization of some of the key equations.

The model is specified with an exogenous rate of Harrod neutral techical progress and can accomadate rik premium on ll assecs. In order to mimic the Blanchard modei de chose a dscount rate for consumplon equal to 58 and a probablitiy of death equal to elther 0.01 or 0.05 dependirg upon the simulation. 
Table Al: Japanese Input-Output Data

Food Manuf Servi Durab Const House Total

\begin{tabular}{|c|c|c|c|c|c|c|c|}
\hline Food & 0 & 0 & 0 & 0 & 0 & 0 & 0 \\
\hline Manufactures & 001 & 268 & 109 & .042 & .067 & 0 & .498 \\
\hline Services & 002 & 098 & 219 & .017 & .041 & 0 & .399 \\
\hline Durabies & 0 & 0 & 0 & 0 & 0 & 0 & 0 \\
\hline Construction & 0 & 0 & 0 & 0 & 0 & 0 & 0 \\
\hline Raw materiais & 001 & 006 & .003 & .002 & .002 & 0 & 014 \\
\hline Energy & .002 & 037 & .006 & .010 & .013 & 0 & .068 \\
\hline Total intermediate & .039 & 409 & .337 & .071 & .123 & 0 & .979 \\
\hline Wage bili & .027 & 119 & .336 & .079 & .079 & 0 & .640 \\
\hline Capital: Equipment & .020 & 013 & .035 & .007 & .007 & 0 & .082 \\
\hline Structures & .000 & 016 & .042 & .009 & .009 & 053 & 129 \\
\hline Land & .020 & 014 & .036 & .007 & .007 & 067 & .251 \\
\hline Halue added & .067 & 162 & $\therefore 449$ & .102 & .102 & 120 & 1.002 \\
\hline
\end{tabular}

Consumption Invest, Govt. Exports Imports GDP

$\begin{array}{lllllll}\text { Food } & .100 & 0 & 0 & 0 & -.030 & .07 \\ \text { Manufactures } & .058 & 0 & .002 & .046 & -.016 & .09 \\ \text { Services } & .300 & 0 & .102 & .028 & .010 & .42 \\ \text { Durables } & .016 & .065 & .013 & .068 & -.010 & .15 \\ \text { Constuction } & 0 & .140 & .080 & 0 & 0 & .22 \\ \text { Housing } & .120 & 0 & 0 & 0 & 0 & .12 \\ \text { Raw Mat+Energy } & 0 & 0 & 0 & 0 & -.082 & -.08\end{array}$




\section{Iable A2: Division of Private Consumption Expenditures}

Consumpeion Expenditures:

of GNP Share

$\begin{array}{lrr}\text { Food } & 10.0 & 16.8 \\ \text { Housing } & 12.0 & 20.2 \\ \text { Services } & 30.0 & 50.4 \\ \text { Other consumer non-durables } & 5.8 & 9.7 \\ \text { Consumer durables } & 1.7 & 2.9 \\ \text { Total } & 59.5 & 100.0\end{array}$

\section{Iable A Inicial values of Asset variables}

Wealth

$\begin{array}{lrr}\text { Human }(p-01) & 754.5 & 62.3 \\ \text { Financial } & 88.7 & 7.3 \\ \text { Capital } & 68.4 & 5.6 \\ \text { Housing } & 300.2 & 24.7 \\ \text { Land } & 0.0 & 0.0 \\ \quad \text { Foreign Assets and Govt bonds } & 3.2 & 0.2 \\ \quad \text { Consurer Durables } & 457.5 & 37.7 \\ \quad \text { Total Financial } & 1212.0 & 100.0 \\ \text { Total } & & \end{array}$




\section{APPENDIX 2 \\ Qutline of Simulaction Model Specification \\ and Parameterization}

The following is an oueline of the behavioural equations of the simulation model discussed in the text. The purpose of this section is to permit the reader to examine the parametization and speciflcation of key equations. A discussion of the reminting equations and the general framework of the model is given in Appendix 2.

\section{Consumers}

Total consumption in terms of the deflator 15 given by:

$$
C=(d+p)(H+C)
$$

where $-C$ real consuption expenditures

H: humen wealth

*: non-human wealth

d: consumer's tate of time preference

p: probability of deach.

Total consumpton is llocsted mongst the various consumpion goods via the following set of nested CES utilicy functions which are maximized subject to the given budget constraint:

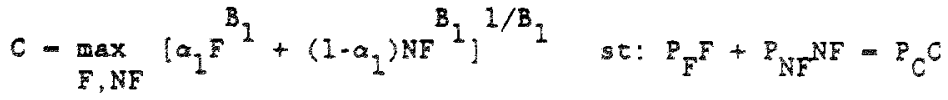

$$
\begin{aligned}
& \mathrm{NF}=\max _{\mathrm{CD}, \mathrm{OD}}\left[a_{2} \mathrm{CD}^{\mathrm{B}_{2}}+\left(1-\mathrm{a}_{2}\right) \mathrm{ND}^{\mathrm{B}_{2}}\right\}^{1 / \mathrm{B}_{2}} s t: \mathrm{P}_{\mathrm{CD}} \mathrm{CD}+z_{\mathrm{ND}} \mathrm{ND}-\mathrm{P}_{\mathrm{NF}} \mathrm{NH}_{\mathrm{F}} \\
& \mathrm{CD}=\max _{\mathrm{H}, \mathrm{OD}}\left[a_{3} \mathrm{H}^{\mathrm{B}_{3}}+\left(1 \cdot \alpha_{3}\right) O D^{B_{3}}\right]^{1 / B_{3}} \text { st: } P_{H} H+{ }_{O D} O D=P_{C D} C D \\
& \left.N D=\max _{S, D N D} \cdot a_{4} s^{B}+\left(1-a_{4}\right) O N D{ }^{B}\right)^{1 / B_{4}} s t: P_{S} S+B_{O N D} O N D=P_{N D} N D
\end{aligned}
$$




\section{Diviston of Consumption Between Imports and Domestic Goods}

Consumption of eradeable goods is allocated between domestically produced and Imported versions via the following Cobb-Douglas function:

$C_{1}=D_{1}, M_{1} D_{1}^{I_{1}^{1-r_{1}}}$

subject to $P_{1}^{D_{1}}+P_{1}^{M_{1}}-P_{1}^{C} C_{1}$

where 1 - I services

2 other non-durables

3 other durables

$C_{1}$ : consumption of good 1 as derived above

$D_{1}, M_{1}$ : consumption of domestically produced and imported version resp.

$P_{1}^{D}, P_{1}$ : price of domestically produced and inported version resp.

\section{Broduction Functions}

$$
\begin{aligned}
& Y_{1}-a_{1} \mathrm{~L}_{1}{ }^{11} \mathrm{KS}_{1}{ }^{12} \mathrm{KE}_{1}{ }^{13} \mathrm{M}_{1}^{\theta}{ }^{14} \mathrm{~S}_{1}^{15} \mathrm{RM}_{1}^{\theta}{ }^{16} \mathrm{E}_{1}^{\theta}{ }^{17} \mathrm{LD}_{1}^{\theta}{ }^{18} \\
& 1 \text { - 1: agrlculture } \\
& \text { 2. services } \\
& \text { 3: manufacturing } \\
& \text { 4: producer durables } \\
& \text { 5: structures }
\end{aligned}
$$

Y: production in sector 1

L: labour input in sector 1

KS: capital stock - structures - In sector 1

$\mathrm{KE}$ : capital stock - equipment - in sector 1

$M$ : inputs of manufactured good in sector 1

S: inputs of services in sector 1

RM: inputs of raw materials in sector 1

$E$ : Inputs of energy in sector 1

LD: inputs of land in sector 1 .

a: constant term 


$$
\sum_{j=1}^{8} b_{1 j}=1 \quad \forall i j \geq 0 \quad \forall 1, j
$$

Factor Inputs are determined by setting the marginai product of each input equal to the cost of the input. Note that land used for structures is frpifiely included in the vilue shre parameter

\section{Investment and Ioblo's o Equations}

Investment in each sector is determined by Tobin's q equations where:

$$
\begin{aligned}
& \left.q s_{1}=1 \sum_{j=t}^{\infty}\left(\frac{\partial Y_{1}}{\partial K S_{1}} P_{1} \frac{P_{F}}{j}\right)_{j}\left((1+\tau)\left(1+\delta_{j}\right)\right)^{-(j-t)}\right] \frac{D E F_{t}}{\partial K S_{t}} \\
& \hat{k} s_{1}=\left(\delta s_{s}+\frac{\left(q s_{1}-1\right)}{A S}\right) K s_{1}
\end{aligned}
$$

Likewlse for $q e_{1}$ and $\dot{K}_{1}$.

where $q s_{1}, q e_{1}$ : Tobin's $q$ for structures and equipment resp.

6s,be: rate of economic depreciation of structures and equipment

AS, AE: adjustment cost parameters for structures and equipment

KE,KS: gross investment in structures and equipment

I : the real interest rate (time dependent in simulations)

\section{inports of Intermediate Inours:}

Incermediate inputs of manufacturers, services and producer durables may be imported or purchased from domestic producers. These are allocated between imports and domestic goods by maximizing 2-level Cobb-Douglas functions which detarmine the an input index, subject to the given budget coristra1nt:

$$
\begin{aligned}
& S_{i}=D S^{I_{S}}{ }^{I_{5}}{ } \text { st } P_{D S} D S+P_{M S} M S-P_{S} S_{1} \\
& M_{i}=D^{r_{6}}{ }^{1-r_{6}} \text { st } P_{D M} D M+P_{M M} M=P_{M} M_{i}
\end{aligned}
$$


$\dot{K} E_{i}=D E^{{ }^{2} 7}{ }_{M E}^{1-r} 7 \quad$ se $P_{D E} D E+P_{M E} M E-P_{P} \dot{K E}$

where: $D S, D M, D E$ : domestically produced services, manufactures, and producer durables

MS , MM , HE: 1mported produced services, manufactures, durables

$P_{D S}{ }^{P} P_{D N}, P_{D E}:$ price of domesticity produced version

${ }^{P}{ }_{M S}, F_{M A}, P_{M E}$ : price of imported version

\section{Structures and Housing:}

As discussed in the ext, we have assumed that each unit of structures and housing require one unit- of the construction good plus fixed amount of land. The initial paramerization may be expressed in value terms, and we have chosen the value shares the nargho of land in the total cost of one unit of structures and housing as ${ }^{\circ},{ }^{H}$ respectively.

\section{Parameter values}

Consuners:

$$
\begin{array}{lll}
\alpha_{1}=0.187 & B_{1}=0 & r_{1}=0.885 \\
\alpha_{2}=0.129 & B_{2}-0 & r_{2}=0.746 \\
\alpha_{3}=0.784 B_{3}=0 & r_{3}=0.569 \\
\alpha_{4}=0.838 B_{4}=0 &
\end{array}
$$

Production functions:

$$
\begin{aligned}
& \theta_{11}=.19 \theta_{12}-.14 \theta_{13}-.14 \theta_{14}-.01 \\
& \theta_{15}=.01 \quad \theta_{16}=.01 \quad \theta_{17}=.01 \quad \theta_{18}=.48 \\
& \theta_{21}=.44 \theta_{22}-.08 \theta_{23}=.04 \quad \theta_{24}-.14 \\
& \theta_{25}=.28 \quad \theta_{26}=.00 \quad \theta_{27}=.01 \quad \theta_{28}=0 \\
& \theta_{31}=.21 \quad \theta_{32}=.04 \quad \theta_{33}=.02 \quad \theta_{34}=.48 \\
& \theta_{35}=.17 \quad \theta_{36}=.01 \quad \theta_{37}=.06 \quad \theta_{38}=0
\end{aligned}
$$




$$
\begin{array}{llll}
\theta_{41}=.46 & \theta_{42}=.08 & \theta_{43}=.04 & \theta_{44}=.25 \\
\theta_{45}=.10 & \theta_{46}=.01 & \theta_{47}=.06 & \theta_{48}=0 \\
\theta_{51}=.36 & \theta_{52}=.06 & \theta_{53}=.03 & \theta_{54}=.30 \\
\theta_{55}=.18 & \theta_{56}=.01 & \theta_{57}=.06 & \theta_{58}=0
\end{array}
$$

Other Parameters:

$$
\begin{array}{lll}
\Sigma_{5}=.987 & \text { AS }-8 & { }_{S}-.04 \\
r_{6}=.965 & \text { AE }=8 & { }_{E}=.14 \\
{ }_{S}=.35 & \\
{ }_{H}=.35 &
\end{array}
$$

